\section{Spectrophotometric Determination of Tin in Zircaloy with Phenylfluorone}

Spektrophotometrische Bestimmung von Zinn in Zircaloy mit Phenylfluoron

Best. von Zinn in Zircaloy; Spektralphotometrie; Phenylfluoron als Reagens

D. Rajkovió

Institute for Technology of Nuclear Raw Materials, Belgrade, Yugoslavia

Received May 13, 1972; revised September 12, 1972

The spectrophotometric determination of tin with phenylfluorone described by Luke [2] has been slightly modified in order to provide a simple and rapid method for the tin determination in Zircaloy.

Investigations on the colour stability showed that in pure Sn solutions the colour is developed completely in 10 min and remains constant during the first hour. After that it begins to fade slowly, decreasing by about $1 \%$ per $\mathrm{h}$ for the following $4 \mathrm{~h}$.

Zirconium, which as the base element makes about $98-99 \%$ of Zircaloys, also reacts with the reagent. Yet, it could be satisfactorily masked by sodium fluoride. The excess of free fluoride should be kept below $1 \mathrm{mg}$ and absorbances measured $1 \mathrm{~h}$ after colour development; variations of $10 \mathrm{~min}$ can be tolerated.

Other elements likely to be present $(\mathrm{Fe}, \mathrm{Ni}, \mathrm{Cr}$ as alloying elements; impurities) did not cause any interferences in the concentrations encountered. The procedure was applied to Zircaloy-2 and Zircaloy-4 samples containing 1.5 and $1.45 \%$ of $\mathrm{Sn}$, respectively. Standard deviation was 0.5 and $1.0 \%$, resp. The results were in good agreement with those obtained by a volumetric method [1].

\section{Experimental}

Calibration Graph. Transfer volumes of standard tin solution containing from 0 to $50 \mu \mathrm{g}$ of $\mathrm{Sn}$ (in $15 \% \mathrm{H}_{2} \mathrm{SO}_{4}$ ) to a series of $50 \mathrm{ml}$ volumetric flasks and add enough $15 \%$ sulphuric acid to make a total of $10.0 \mathrm{ml}$ in each flask. Add $10 \mathrm{ml}$ of saturated boric acid solution, $10 \mathrm{ml}$ of a $\mathrm{CH}_{3}-$ $\mathrm{COONa} / \mathrm{CH}_{3} \mathrm{COOH}$ buffer solution $\mathrm{pH} 5,1 \mathrm{ml}$ of $0.2 \%$ gelatin solution and $10.0 \mathrm{ml}$ of $0.01 \%$ phenylfluorone solution (in ethanol), swirling after each addition. Dilute to volume with water and mix well. After $1 \mathrm{~h}$ read the absorbances at $510 \mathrm{~nm}$ against water.

Sample Preparation. Weigh $0.100 \mathrm{~g}$ of sample in a platinum dish and add enough water to cover the sample. Add $2 \mathrm{mI}$ of cono. sulphuric acid and cover the dish with a plastic lid. Add carefully under the cover about $1 \mathrm{ml}$ of $38-40 \%$ hydrofluoric acid, a few drops at a time, as the reaction permits. Heat gently until complete solution is obtained. Uncover and rinse the lid and the sides of the dish with water. If some black residue remains, add a few drops of nitric acid and dissolve by heating. Evaporate the solution, increasing the temperature gradually, until white fumes evolve. Cool, wash down the sides of the dish with some water, and continue with heating at first at a moderate and later at a higher temperature to expel the excess of sulphuric acid.

Avoid an excessively high temperature in order to prevent baking. Cool, dissolve the salts in $15 \%$ sulphuric acid and transfer the solution to a $100 \mathrm{ml}$ volumetric flask rinsing the dish with the same acid. Make up to volume with $15 \%$ sulphurio acid and mix. Pipette a $2 \mathrm{ml}$ aliquot (a $5 \mathrm{ml}$ aliquot in the case of Zircaloy-3) to a $50 \mathrm{ml}$ volumetric flask. Add enough $15 \%$ sulphuric acid to make a total of $10.0 \mathrm{ml}$. Add in the following order: $3 \mathrm{ml}$ of sodium fluoride solution $(1 \mathrm{mg} \mathrm{F}-/ \mathrm{ml})$, (7 ml to a $5 \mathrm{ml}$ sample aliquot), $10 \mathrm{ml}$ of saturated boric acid solution, $10 \mathrm{ml}$ of buffer solution, $1 \mathrm{ml}$ of $0.2 \%$ gelatin solution and $10 \mathrm{ml}$ of phenylfluorone solution, swirling after each addition. After $1 \mathrm{~h}$ measure the absorbance and correct the obtained value for a reagent blank. Calculate the content of tin in the sample referring to the calibration graph.

\section{References}

1. Commissariat à l'Energie Atomique, Commission d'Etablissement des Methodes d'Analyse: Methodes d'Analyse, Rapp. No 81 (1961).

2. Luke, C. L.: Anal. Chem. B1, 1803 (1959).

Dr. D. Rajković

Inst. for Technology of

Nuclear Raw Materials

Franše Depere 86

YU-11 Belgrade

Yugoslavia 